\title{
Relationship Between Commercial Bank Availability and Income Inequality: Evidence From SAARC Countries
}

\author{
Aman Takiyar, Birla Institute of Technology and Science, Pilani, India \\ Varun Chotia, Jaipuria Institute of Management, India
}

\begin{abstract}
The objective of this study is to examine the relationship between commercial bank branches availability and income inequality. Further, the study also assesses the interaction effect of corruption and commercial bank availability on income inequality. The present study uses panel data estimation methods for analysing the above relationship for SAARC countries (Afghanistan, Bangladesh, Bhutan, India, Nepal, Pakistan, and Sri Lanka). The analysis suggests that a positive relationship exists between income inequality and financial availability in the initial stages. However, as the financial institutions reach a level of maturity and more people are integrated in the financial network, the level of income inequality starts reducing. Moreover, increase in financial availability helps in reducing income inequality when it is supported by less corrupt institutions. Policymakers should focus on reducing the level of corruption so as to enhance the effectiveness of the penetration of commercial bank branches.
\end{abstract}

\section{KEYWORDS}

Commercial Bank Branches, Corruption, Income Inequality, SAARC Countries

\section{INTRODUCTION}

Income inequality is a persistent phenomenon and a fundamental issue of concern. In the last few decades, researchers have tried to search out for the many sources of income inequality and subsequently, the adverse consequences it has on the social and economic conditions of the world. It behoves the researchers to carefully examine the link between financial sector development and income inequality as financial systems have the potential to equalize opportunities across people, communities, and nations of differing income groups. On the contrary, even due to the increasing financial liquidity and size of financial system the poorer section of the society may not always be benefitted. This is due the fact that access to financial services and knowledge about them is not yet democratized. In other words, if the access to financial services for the poor is limited compared to the rest of the population, financial development may not contribute to reducing income inequality. 
It was in the early 1970s that the prevalence of high-income inequality within developing countries attracted attention of many economists. Notwithstanding this, most of the economists held the view that ensuring economic growth was far more important and effective that tackling income inequality for poverty reduction. Fortunately for the poor, this long-standing view has been contested since 2000. Importance of equity of income levels has been associated with lowering poverty and human development broadly. It is more evident today than ever before that high levels of income inequality, though by-product of sustainable past economic progress, are an obstacle to an inclusive future development.

Levine (2005) states that a large section of literature points to the direction that development of financial sector leads to faster economic growth though researchers are inconclusive as to whether this development benefits the entire population equally or not. If the financial development enhances the levels of income inequality, this setback will offset the gains to the society resulting from the financial development itself (Ang, 2010; Beck et al., 2007). Additionally, it is a widely acknowledged fact that widespread corruption in societies breaks down governance systems at the grassroot and that in turn exacerbates income inequality. This may happen in spite of increased financial development.

The paper is structured with Introduction discussed above in Section 1, followed by Literature Review in Section 2. The Data and Model is elaborated in Section 3 while Section 4 talks about the Empirical Analysis and Discussion. Finally, Conclusions and Policy Implications have been mentioned in Section 5.

\section{LITERATURE REVIEW}

Widening income inequality, with significant and adverse implications for economic growth and macroeconomic stability, is the defining challenge of present times. Income inequality can have numerous far-reaching effects such as: sub-par allocation of human resources, political and economic instability leading to reduction in investments, increased crisis risk, etc. The global financial crisis of 2008 and the concomitant reduction in economic growth and increased unemployment have directed the attention to rising income inequality. Levine $(1999,2005)$ states that a voluminous literature has found a strong and robust link between financial development and economic growth. Even recent studies such as Beck, Kunt and Levine (2007), and Clark, Xu and Zou (2006) have come to the same conclusion. Earlier theoretical works by Galor and Zeira (1993) and Banerjee and Newman (1993) emphasise the importance of financial development in eradicating income inequality. Both the above studies conclude that there exists an inverse relationship between financial development and income inequality due to financial market imperfections and lumpy investments.

Greenwood and Jovanovic (1990) add to the above findings by arguing that there exists a nonlinear (inverted U-shaped) relationship between financial development and income inequality. It is only after when some time passes that people have access to the financial services and this leads to reduction in income inequality. During the initial phase of financial development, it is only the rich who are benefitted. Theoretically speaking, there are conflicting views as for the impact of financial development on the distribution of income. Beck et al. (2007) states that financial development affects the poor section of the society in two ways: through aggregate economic growth and changes in the distribution of income. Their findings suggest that financial development reduces income inequality. Other studies suggest that imperfections in the financial sector (such as transaction costs and asymmetric information) are binding on the poorer sections of the society because of their lack of credit history and substantial collateral. Galor and Moav (2004) state that this leads to reduced capital allocation efficiency and as the flow of capital to poorer sections of society is impeded, income inequality increases.

In his seminal study, Kuznets (1995) states that there may be a non-linear (inverted U-shaped) relationship between financial development and income inequality. Greenwood and Jovanovic (1990), building on his hypothesis, conclude that the development of the financial systems and their 
increased sophistication initially leads to increase in income inequality, which then stabilizes and eventually declines. Inequality declines as more and more people are included in the financial system (thus, the inverted U-shaped hypothesis). On the other hand, Bhattacharya (2011) finds evidence on the inverted $U$ hypothesis, especially for those economies where migration of both low and high skilled workers from rural to urban areas is prevalent. He asserts that once the Gini coefficient has undergone an inverted U-shaped cycle along with increasing financial development, the inequality may not continuously decline; inequality may rise again over the previous peak.

Some studies even suggest that in the long run, converge in the income levels of rich and poor may not be possible (Greenwood and Jovanovic (1990), Banerjee and Newman (1993), Galor and Zeira (1993)). This is because of the two most prevalent condition in the economies: imperfections in capital markets and indivisibilities in investment in human or physical capital. Consequently, they predict an inverse and linear relationship between financial sector development and inequality. Thus, these studies suggest that instead of using financial development as a tool, governments should implement appropriate public policies to ensure the redistribution of income from rich to the poor.

Much of the existing literature in the given context focuses on the macro perspective by the studying the relationship between the size of the financial sector (banking sector and stock markets) and income inequality. Only recently a small subset of this literature has tried to explore the link between inequality and financial development through financial inclusion, which provides analysis about a more micro perspective. It is quite pertinent to look into the aspects of financial access and how it channels the effects of financial development on inequality because access to financial services is still very uneven, especially in developing countries. Burgess and Pande (2005) states that with increased access to finance in rural areas in India, both poverty and output also increased. More recent work by Classens and Perotti (2007) provide more details on the importance of role of finance, financial inclusion and their impact on mitigating income inequality.

But no studies have explored the link between access to finance and income inequality in SAARC nations. As a result, and unlike earlier studies, this paper employs a more micro focused measure as a proxy for financial development and access to financial services, which better captures how financial development potentially impacts income inequality. Based on the above discussion, this study attempts to empirically gauge the relationship between financial development and income inequality for a sample of SAARC nations.

\section{DATA AND MODEL}

Gini coefficient is a widely used and accepted indicator of income inequality. Also, what makes Gini coefficient widely used is its easy availability and understandability. Some of the criteria for a good measure of income inequality - like mean independence, population size independence, symmetry and Pigou-Dalton Transfer sensitivity - are satisfied by the Gini coefficient (Poverty Manual (All, JH Revision, 2005)). This study uses Gini coefficient data from UN HDI database for SAARC countries (except Maldives). The time period chosen is 2005 to 2017. To proxy for financial development, the indicator used is commercial bank branches per 100,000 adults. Data on this has been obtained from the World Bank dataset. As mentioned earlier, using the above indicator for capturing financial development, enables ones to have more micro level focus on the extent of financial penetration. The indicator, commercial bank branches is chosen because of its close relation to the measures of financial development (Beck et al., 2006).

Along with studying the impact of financial availability on income inequality, the focus is also on the impact of corruption, which may act as a deterrent for equalising income distribution across the SAARC region. For this purpose, so as to capture the extent of corruption prevalent in a country, the study uses the Corruption Perception Index compiled by the international non-governmental organization named Transparency International. For each year, a country is awarded a value on a scale of 0 to 100, where 0 means no corruption and 100 means full of corruption. Before 2011, the 
ratings were awarded on a scale of 0 to 10 . Necessary scaling adjustments have been made for the purpose of this study.

This study also employs several other control variables that are widely used in existing literature. The control variables include per capita GDP, consumer price index, trade openness, and mobile subscriptions per 100 people. The data for the above variables has been obtained from the World Bank database. For the purpose of the study, the following models have been estimated. Results for the above models have been estimated using the fixed effects estimation methods.

\section{MODEL 1:}

$$
\begin{aligned}
& \text { GINI }_{i t}=\beta_{1} \cdot \ln (B B R A N C H)_{i t}+\beta_{2} \cdot \ln (P C G D P)_{i t}+\beta_{3} \cdot \ln (C P I)_{i t} \\
& +\beta_{4} \cdot \ln (T O)_{i t}+\beta_{5} \cdot M O B_{i t}+\beta_{6} \cdot C R R I_{i t}+\gamma_{i}+u_{i t}
\end{aligned}
$$

\section{MODEL 2:}

$$
\begin{aligned}
& \text { GINI }_{i t}=\beta_{1} \cdot \ln (B B R A N C H)_{i t}+\beta_{2} \cdot(\ln (B B R A N C H)) \wedge 2_{i t}+\beta_{3} \cdot \ln (P C G D P)_{i t} \\
& +\beta_{4} \cdot \ln (C P I)_{i t}+\beta_{5} \cdot \ln (T O)_{i t}+\beta_{6} \cdot M O B_{i t}+\beta_{7} \cdot C R R I_{i t}+\gamma_{i}+u_{i t}
\end{aligned}
$$

\section{MODEL 3:}

$$
\begin{aligned}
& G I N I_{i t}=\beta_{1} \cdot \ln (B B R A N C H)_{i t}+\beta_{2} \cdot \ln (P C G D P)_{i t}+\beta_{3} \cdot \ln (C P I)_{i t}+\beta_{4} \cdot \ln (T O)_{i t} \\
& +\beta_{5} \cdot M O B_{i t}+\beta_{6} \cdot C R R I_{i t}+\beta_{7} \cdot(\ln (B B R A N C H) \cdot C R R I)_{i t}+\gamma_{i}+u_{i t}
\end{aligned}
$$

Using model 1, the direct relationship between financial availability and income inequality can be studied; whereas in model 2, an attempt has been made to investigate the linearity of the relationship. This helps to understand whether growing financial availability and development has the same impact as that in the initial phase. Model 3 investigates the interaction between corruption and the financial availability and thus, helps to understand what impact the growing financial development on the level income inequality in the presence of increasing corruption.

\section{EMPIRICAL ANALYSIS AND DISCUSSION}

As per model 1, there is a positive relation between the number of commercial bank branches and Gini coefficient. This goes to say that as the level of financial development / availability (specifically, in the form of number of commercial bank branches) increases the level of income inequality also increases. These findings are in line with Burgess and Pande (2005), according to whom greater access to bank branches in rural India (which accounts for the majority of the SAARC region) leads to not only increased output but also increased poverty. This is because in the initial stages of financial development, only the wealthy people may benefit because of weak institutional quality and poor governance (Clarke et al., 2006). Rich people benefitted because of their credit worthiness to the banks. Due to lack of collateral and financial creditworthiness, poor people suffer.

Model 2 confirms that there is a non-linear inverted- $U$ relationship between income inequality and availability of commercial bank branches. This further complements the analysis in model 1 and is supported by the conclusions put forth in the study by Greenwood and Jovanovic (1990). Initially, as stated above, the wealthy class of society benefits from the increased level of financial development 
and financial availability. But as the economic growth and level of financial development / availability matures, the poor class of society is also linked into the financial network.

Model 3 suggests that as the level of corruption reduces, increased availability of commercial bank branches reduces income inequality. Thus, corruption control along with increasing financial development helps in more equitable income distribution. Law et al. (2014) report that the relation between financial development and income inequality is dependent on the quality of institutions. The study states that financial development reduces income inequality only if there is a presence of a certain level of institutional quality (Table 1).

\section{CONCLUSION AND POLICY IMPLICATIONS}

Based on the above results it can be noted that financial inclusion measures (in the above specific case, availability of commercial bank branches) are beneficial to the poorer section of the society after a certain level of financial sector development. At the initial levels of development of financial sector, income inequality tends to worsen. To provide greater access to banks and their services especially in developing countries, policymakers should pursue policies that foster more competition in the banking sector, through greater deregulation and privatization (Cull (2001), and Hryckiewicz and Kowalewski (2010)).

As shown by the above analysis, increase in commercial bank branches leads to reduction in income inequality at lower levels of corruption. Corruption is one detrimental factor which stops

Table 1. Reports the results for the models stated previously

\begin{tabular}{|c|c|c|c|}
\hline & Model 1 & Model 2 & Model 3 \\
\hline \multirow[t]{2}{*}{ Bank Branches } & $0.037 * *$ & $0.016^{*}$ & $0.102 * * *$ \\
\hline & $(0.033)$ & $(0.064)$ & $(0.000)$ \\
\hline \multirow[t]{2}{*}{ Bank Branches ^ 2} & 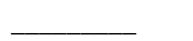 & $-0.005^{*}$ & - \\
\hline & & $(0.098)$ & \\
\hline \multirow[t]{2}{*}{ Per capita GDP } & $0.092 * * *$ & 0.011 & $0.117 * * *$ \\
\hline & $(0.000)$ & $(0.296)$ & $(0.000)$ \\
\hline \multirow[t]{2}{*}{ CPI } & -0.018 & -0.023 & -0.034 \\
\hline & $(0.837)$ & $(0.214)$ & $(0.678)$ \\
\hline \multirow[t]{2}{*}{ Trade Openness } & 0.027 & $0.024 * * *$ & $0.069^{* * *}$ \\
\hline & $(0.169)$ & $(0.006)$ & $(0.003)$ \\
\hline \multirow[t]{2}{*}{ Mobile Subs. } & $0.001 * * *$ & 0.000 & $0.001 * *$ \\
\hline & $(0.001)$ & $(0.821)$ & $(0.020)$ \\
\hline \multirow[t]{2}{*}{ Corr. Perc. Index } & $-0.028 * * *$ & 0.001 & $0.039 *$ \\
\hline & $(0.000)$ & $(0.845)$ & $(0.090)$ \\
\hline \multirow[t]{2}{*}{ Bank Br. X Corr. Perc. Index } & 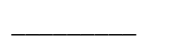 & 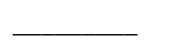 & $-0.031 * * *$ \\
\hline & & & $(0.002)$ \\
\hline Number of Observations & 91 & 91 & 91 \\
\hline Countries & 7 & 7 & 7 \\
\hline \multicolumn{4}{|l|}{ Dependent variable is Gini coeff. } \\
\hline $\mathrm{p}$-values are shown in brackets $b$ & ents & & \\
\hline
\end{tabular}


the reduction of income inequality and it has always been one of most important problematic issue in most of SAARC nations. Thus, governments in SAARC countries should formulate policies to ensure mitigation of the adverse distributional consequences of corruption. Such policies may be directed towards: (i) proper management of natural resources, (ii) equitable access to primary and secondary education in villages and (iii) encouragement for labour-intensive growth. Focus on Social Infrastructure is a must as it not only builds the social capital of the nation, but also helps in mitigating other related issue of financial literacy also. Financial literacy helps the consumers to be more aware about the financial setup around them and all the related features which the financial setup gives them. This ensures that they are completely aware of all the policies which helps in fighting corruption and thereby addressing the aspect of income inequality. Ultimately, countries can move towards a better level of financial services availability through banks. 


\section{REFERENCES}

Ang, J. B. (2010). Finance and inequality: The case of India. Southern Economic Journal, 76(3), 738-761. doi:10.4284/sej.2010.76.3.738

Banerjee, A. V., \& Newman, A. F. (1993). Occupational choice and the process of development. Journal of Political Economy, 101(2), 274-298. doi:10.1086/261876

Beck, T., Demirgüç-Kunt, A., \& Levine, R. (2007). Finance, inequality and the poor. Journal of Economic Growth, 12(1), 27-49. doi:10.1007/s10887-007-9010-6

Beck, T., Demirguc-Kunt, A., \& Martinez Peria, M. S. (2006). Banking services for everyone? Barriers to bank access and use around the world. The World Bank. doi:10.1596/1813-9450-4079

Bhattacharya, P. C. (2011). Informal sector, income inequality and economic development. Economic Modelling, 28(3), 820-830. doi:10.1016/j.econmod.2010.10.007

Burgess, R., \& Pande, R. (2005). Do rural banks matter? Evidence from the Indian social banking experiment. The American Economic Review, 95(3), 780-795. doi:10.1257/0002828054201242

Claessens, S., \& Perotti, E. (2007). Finance and inequality: Channels and evidence. Journal of Comparative Economics, 35(4), 748-773. doi:10.1016/j.jce.2007.07.002

Clarke, G. R., Xu, L. C., \& Zou, H. F. (2006). Finance and income inequality: What do the data tell us? Southern Economic Journal, 72(3), 578-596. doi:10.2307/20111834

Cull, R. (2001). Financial-sector reform: What works and what doesn't. Economic Development and Cultural Change, 49(2), 269-290. doi:10.1086/452502

Galor, O., Moav, O., \& Vollrath, D. (2004). Land inequality and the origin of divergence and overtaking in the growth process: theory and evidence. Academic Press.

Galor, O., \& Zeira, J. (1993). Income distribution and macroeconomics. The Review of Economic Studies, 60(1), 35-52. doi:10.2307/2297811

Greenwood, J., \& Jovanovic, B. (1990). Financial development, growth, and the distribution of income. Journal of Political Economy, 98(5, Part 1), 1076-1107. doi:10.1086/261720

Hryckiewicz, A., \& Kowalewski, O. (2010). Economic determinates, financial crisis and entry modes of foreign banks into emerging markets. Emerging Markets Review, 11(3), 205-228. doi:10.1016/j.ememar.2010.05.003

Kuznets, S. (1955). Economic growth and income inequality. The American Economic Review, 45(1), 1-28.

Law, S. H., Tan, H. B., \& Azman-Saini, W. N. W. (2014). Financial development and income inequality at different levels of institutional quality. Emerging Markets Finance and Trade, 50(sup1), 21-33.

Levine, R. (1999). Financial development and economic growth: views and agenda. The World Bank. doi:10.1596/1813-9450-1678

Levine, R. (2005). Finance and growth: theory and evidence. Handbook of Economic Growth, 1, 865-934.

Aman Takiyar is currently working as a Research Scholar in Economics and Finance Department at Birla Institute of Technology and Science, Pilani (BITS, Pilani). He completed his Master of Science (Hons.) in Economics and Bachelor of Engineering (Hons.) in Mechanical from BITS Pilani in 2017. He worked as a Market Risk Analyst for Deutsche Bank from 2017 to 2018.

Varun Chotia (PhD) is presently working as Assistant Professor, Economics at Jaipuria Institute of Management, Jaipur campus, Rajasthan, India. Prior to this, he has worked at LM Thapar School of Management, Thapar Institute of Engineering and Technology (Deemed to be a University). He has completed his PhD in Economics from Department of Economics and Finance, Birla Institute of Technology and Science, Pilani (BITS Pilani). Before coming into academics, he has around two years of industry experience in corporate firms like IMS Health and Accenture Management Consulting. He has authored number of research papers in international and national journals of high repute. 